\title{
THE IMPORTANCE OF H-Y INCOMPATIBILITY IN HUMAN ORGAN TRANSPLANTATION ${ }^{1}$
}

\author{
E. Goulmy, B. A. Bradley, Q. Lansbergen, and J. J. van Rood \\ Department of Immunohaematology, University Hospital, Leuden, The Netherlands
}

\section{SUMMARY}

As an extension of our first observation in which the peripheral blood lymphocytes of an aplastic amaemia patient with a transplant were able to show HLA-restricted H-Y killing in a cell-mediated lympholysis assay, we report here a second case showing exactly the same phenomenon.

A multitransfused woman suffering from aplastic anaemia was shown to have in vitro killing after priming her lymphocytes with her HLA-identical brother. This killing was directed to all male target cells carrying the HLA-A2 antigen. Marginally, killing was also directed to some HLA-A2 female target cells, but this was at a considerably lower level than that directed to male cells. The level of HLA-restricted H-Y killing declined with time. However, it was possible to reactivate the $\mathrm{H}-\mathrm{Y}$ specific killing by in vitro stimulation with lymphocytes from an HLA-A, -B, and -C-identical, but HLA-D-different male donor. That these findings could be relevant for renal transplantation was supported by renal allograft survival data obtained at 2 years after transplantation. Male allografts from HLA-A2-positive donors in A2-positive females survived for a significantly shorter time than non-A2 male kidneys in non-A2 female recipients. This was only apparent in recipients who produced antileukocyte antibodies.

Observations in the mouse have shown that gene products coded for on the $\mathrm{Y}$ chromosome can play a role in graft rejection (4). In various strains, skin grafts from males are rejected by isologous females and it is possible to generate cytotoxic $\mathrm{T}$ cells which specifically kill male cells $(5,15)$. We have recently described the case of a woman who had been hyperimmunized by pregnancies, blood transfusion, and a bone marrow graft from an HLA-identical sibling donor (7). She had developed effector cells against all male phytohaemagglutinin blasts that were positive for HLA-A2, an antigen that she shared with her brother who donated the bone marrow.

In this publication we show that, although with time the level of killing declined almost to background, it could be recalled by restimulation with HLA-A and -B-identical, but HLA-D non-identical lymphocytes from an unrelated male donor. A second patient showing the same phenomenon is also described. Furthermore, the possible relevance of this finding for renal transplantation is discussed.

\section{MATERIALS AND METHODS}

The cell-mediated lympholysis (CML) assay used has been previously described in detail (6). Briefly, cytotoxicity was measured using an isotope release assay with target cells that

\footnotetext{
${ }^{1}$ Supported in part by the National Institutes of Health contract NO1-AI-4-2508, the J. A. Cohen Institute for Radiopathology and Radiation Protection (IRS), the Dutch Foundation for Medical Research (FUNGO) which is subsidized by the Dutch Organization for the Advancement of Pure Research (ZWO), the Dutch Organization for Health Research (TNO), the Eurotransplant Foundation, and the Foundation De Drie Lichten.
}

had been incubated with phytohaemagglutinin for 3 days and then labelled with $100 \mu \mathrm{c}$ of ${ }^{51} \mathrm{Cr}\left({ }^{51} \mathrm{Cr} \mathrm{Na} \mathrm{Cr} \mathrm{O}_{4}, 5 \mathrm{mc} / 5 \mathrm{ml}\right.$; specific activity 100 to $350 \mathrm{mc} / \mathrm{mg}$, Amersham CJS 1P) for $1 \mathrm{hr}$ at $37 \mathrm{C}$. The effector cells were collected from the tissue culture flasks after 6 days in culture using $8 \times 10^{6}$ responder cells and $16 \times 10^{6}$ stimulator cells. Effector cells $\left(70,50\right.$, and $\left.25 \times 10^{4}\right)$ and target cells $\left(1 \times 10^{4}\right)$ in RPMI-1640 medium plus $20 \%$ heatinactivated human $\mathrm{AB}$ serum were incubated for $4 \mathrm{hr}$ in roundbottomed microtiter plates. After incubation the plates were centrifuged for $5 \mathrm{~min}$ at $200 \mathrm{~g}$, and the supernatant was removed and counted in a gamma counter. All combinations were tested in triplicate. The variation coefficient within the triplicates was less than $10 \%$.

The degree of chromium release of a target was found to vary between target cells. Some cells gave very high spontaneous release while others gave low spontaneous release. Because of this, the degree of specific release could not simply be expressed as an index of spontaneous release. It was further noted that a linear relationship existed between the level of spontaneous release and the level of maximum release on freeze-thawing (Fig. 1). Thus the data were expressed on a scale on which $0 \%$ was made equivalent to the spontaneous release value and $100 \%$ was made equivalent to the freeze-thaw value. This was calculated for each target cell using the following formula:

$$
\begin{aligned}
& \text { experimental mean - } \\
& \frac{\text { mean of spontaneous release }}{\text { freeze-thaw mean }(100 \% \text { release) }} \\
& - \text { mean of spontaneous release }
\end{aligned}
$$

Percentages lower than $10 \%$ were considered negative. All experiments were repeated at least once.

Effector cells from two female patients are described in this paper.

Patient 1. Mrs. R. had been suffering from a severe aplastic anaemia. She had had four pregnancies, received more than 100 units of blood and blood products, and, after antithymocyte globulin pretreatment, bone marrow from her HLA-identical brother.

Patient 2. Mrs. K. suffered from aplastic anaemia. She had had three pregnancies and received more than 20 units of blood or blood products. She did not receive a transplant.

All individuals were typed for $H L A-A,-B$, and $-C$ and in some cases also for $H L A-D$ locus products. The results of cadaveric renal allograft survival were collected under the auspices of the Eurotransplant Organization. No distinction was made between first and second grafts and all were included in the analysis.

\section{RESULTS}

Until now we have studied a group of 14 aplastic anaemia patients including males and females and HLA-A2-positive and -negative individuals. In five patients positive CML reactions 
were detected against HLA-identical target cells, and in three of these killing was also detected against cells of HLA-identical siblings. These latter three were female patients carrying HLAA2 and they were able to kill the cells of their HLA-identical male siblings. Extensive segregation studies have now been completed in two of these individuals, using families and panels of unrelated individuals. They indicated that the target antigen was coded for by the $Y$ chromosome and was a probable human equivalent of the $\mathrm{H}-\mathrm{Y}$ histocompatibility antigen in rodents.

$15-$

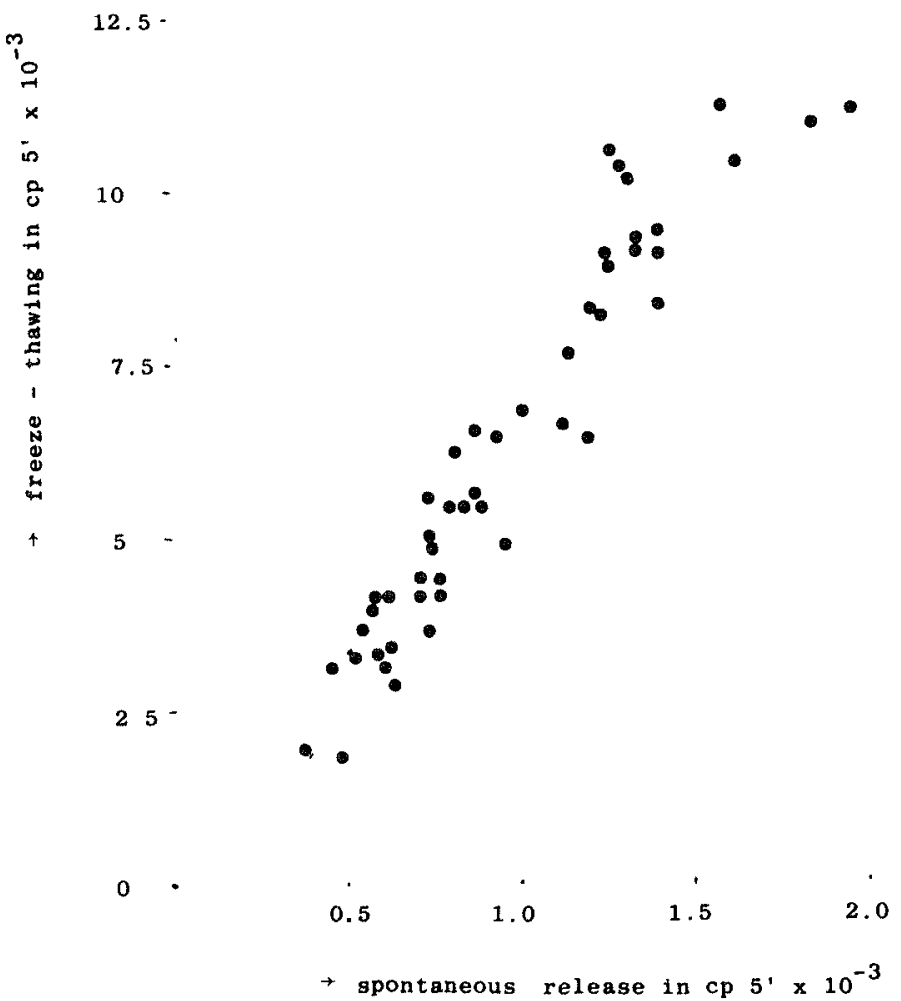

FIGURE 1. Relationship between spontaneous release and freeze-thaw values.
Preliminary data also suggested that a similar phenomenon occurred in a recently studied third patient

$H$-Y-specific cytotoxicity. The pattern of killing obtained with effector cells of patient 2 (Mrs. K.) after restimulating in vitro against members of her family showed that the target antigen was not a product of the HLA region per se (Table 1). The patient had two HLA-identical siblings (sib), a sister (sib 1) and a brother (sib 2). When cells from sib 1 were used for restimulating, they failed to generate cytotoxic cells but when sib 2 cells were used cytotoxic cells were generated. They were capable of killing target cells from both sib 2 and the father. Furthermore, the cytotoxic cells generated when the father's lymphocytes were used for restimulation were able to kill cells from sib 2 but not from sib 1.

Despite this nonsegregation with the HLA haplotype when panel studies were performed using a series of target cells derived from unrelated individuals, an association with HLA was found. Effector cells were made using patient 2 restimulated to sib 2 and these were tested on the panel (Table 2). All male HLA-A2-positive target cells gave a high percentage of killing ( 32 to $53 \%$ ), whereas non-A2 male cells gave zero killing ( -1 to $-2 \%$ ). A variable degree of killing at a low level was shown by HLA-A2-positive female target cells ( -2 to $17 \%$ ), but non-A2 female target cells gave zero killing $(-3$ to $+1 \%)$.

Memory and recall of the phenomenon. Patient 1 was studied on seven occasions between the 25 th and the 74 th week after transplantation. A consistent decline was found in the killing of the HLA-identical brother's cells (Table 3). After 1 1/2 years the level of kill was only slightly above background. Nevertheless, it was possible to recall the $\mathrm{H}$-Y-specific effector cells by an in vitro stimulation using lymphocytes from an HLA-A, -B, and -C-identical but HLA-D-different donor (Table 4). Such effector cells retained their specificity for HLA $-A 2$ males as seen in the repeat panel study shown in Table 5 .

Possible relevance in renal transplantation. Cadaveric renal allograft survival data, collected under the auspices of Eurotransplant, were examined 2 years after transplantation for the influence of sex. It was found that a significant difference existed between HLA-A2 females who received HLA-A2 male kidneys and non-HLA-A2 females who received non-HLA-A2 male kidneys (Table 6). This occurred only in those patients who produced antibodies to leukocytes but not in the antibodynegative group. The data are compatible with the assumption that $\mathrm{H}-\mathrm{Y}$ incompatibility in donor-recipient combinations that

TABLE 1. Killing pattern of cells from patient 2 (Mrs. K. against her family)

\begin{tabular}{|c|c|c|c|c|c|c|}
\hline \multirow{2}{*}{$\begin{array}{l}\text { Responder } \times \text { stimulator } \\
\text { (sensitizing haplotype) }\end{array}$} & \multirow{2}{*}{$\begin{array}{l}\text { Stimulation index in mixed } \\
\text { leukocyte culture }\end{array}$} & \multicolumn{5}{|c|}{ Target cells ${ }^{\alpha}$ (haplotypes-sex) } \\
\hline & & Father $(a b)$ & Mother $(c d)$ & $\begin{array}{l}\text { Patient ( } a c \text {-fe- } \\
\text { male) }\end{array}$ & Sib 1 (ac-female) & Sib 2 (ac-male) \\
\hline Patient $\times$ father $(b)$ & 4,8 & $72^{b}$ & 5 & -2 & 1 & 62 \\
\hline Patient $\times$ mother $(d)$ & 3,4 & 2 & 1 & -2 & -1 & -1 \\
\hline Patient $\times$ sib $1(-)$ & 1,8 & $\mathrm{NTT}^{c}$ & NT & -2 & -2 & NT \\
\hline Patient $\times \operatorname{sib} 2(-)$ & 3,1 & 45 & NT & -2 & -2 & 45 \\
\hline Sib $2 \times$ patient $(-)$ & 1,1 & NT & NT & NT & NT & NT \\
\hline
\end{tabular}

${ }^{a}$ HLA haplotypes:

a: 2 W15.2 W6 CW3

b: 9 W6

c: 3 W40 W6

d: $28 \quad 7 \quad$ W6

${ }^{b}$ Figures represented percentage of Cr release; effector to target ratio $=70: 1$.

'NT, not tested. 
TABLE 2. Killing of target cells from unrelated individuals by cells from patient 2 (Mrs. K.), stimulated in vitro with her HLA-identical male sib

\begin{tabular}{|c|c|c|c|c|c|c|c|}
\hline \multirow{3}{*}{$\begin{array}{c}\text { Targets } \\
\text { Patient } 2\end{array}$} & \multicolumn{5}{|c|}{ HLA phenotypes } & \multirow{3}{*}{$\frac{\text { Sex }}{\text { Female }}$} & \multirow{3}{*}{$\frac{\% \mathrm{kill}^{\circ}}{0}$} \\
\hline & & $H L A-A$ & \multicolumn{2}{|c|}{$H L A \cdot B$} & \multirow{2}{*}{$\frac{H L A-C}{\mathrm{CW} 3}$} & & \\
\hline & $\underline{2}^{b}$ & $\underline{3}$ & W15.2 & W40 & & & \\
\hline Brother & $\underline{2}$ & $\underline{3}$ & $\overline{\mathrm{W} 15.2}$ & $\overline{\mathrm{W} 40}$ & $\overline{\mathrm{CW} 3}$ & Male & 44 \\
\hline 1 & $\underline{\overline{2}}$ & $\underline{\overline{3}}$ & $\overline{\mathrm{W} 15.2}$ & $\overline{\mathrm{W} 40}$ & $\overline{\mathrm{CW3}}$ & Male & 32 \\
\hline 2 & $\overline{1}$ & $\underline{\overline{2}}$ & 8 & $\overline{\mathrm{W} 40}$ & $\overline{\mathrm{CW} 3}$ & Male & 53 \\
\hline 3 & $\underline{2}$ & $\underline{3}$ & 7 & 12 & - & Male & 43 \\
\hline 4 & $\underline{2}$ & & 12 & $\underline{\mathrm{W} 40}$ & CW3 & Male & 48 \\
\hline 5 & $\overline{1}$ & $\underline{2}$ & 8 & 27 & $\overline{C W 2}$ & Male & 51 \\
\hline 6 & $\underline{3}$ & W25 & 7 & W39 & - & Male & -2 \\
\hline 7 & 二 & $\underline{3}$ & 18 & W17 & - & Male & -2 \\
\hline 8 & - & $\underline{3}$ & 18 & 27 & CW2 & Male & -2 \\
\hline 9 & 1 & $\overline{9}$ & 8 & 27 & $\mathrm{CW} 1$ & Male & -1 \\
\hline 10 & $\underline{2}$ & W32 & 8 & $\underline{W 15.2}$ & CW3 & Female & 7 \\
\hline 11 & $\underline{2}$ & $\underline{3}$ & 7 & 12 & - & Female & 17 \\
\hline 12 & $\underline{2}$ & $\underline{3}$ & 7 & $\underline{\mathrm{W} 40}$ & CW3 & Female & 10 \\
\hline 13 & $\underline{2}$ & $\underline{3}$ & 7 & $\overline{12}$ & $\overline{-}$ & Female & 13 \\
\hline 14 & $\underline{2}$ & $\underline{3}$ & W17 & W35 & CW4 & Female & 10 \\
\hline 15 & $\underline{2}$ & $\underline{3}$ & 7 & W35 & CW4 & Female & 8 \\
\hline 16 & $\underline{2}$ & 11 & & W35 & CW4 & Female & 6 \\
\hline 17 & $\underline{2}$ & $\underline{3}$ & W22 & W35 & CW4 & Female & -2 \\
\hline 18 & $\underline{2}$ & 9 & & 5 & - & Female & 11 \\
\hline 19 & $\underline{2}$ & - & 8 & 12 & - & Female & 8 \\
\hline 20 & 1 & 28 & 5 & 8 & - & Female & -3 \\
\hline 21 & 11 & W31 & W15.2 & W17 & CW3 & Female & -1 \\
\hline 22 & 1 & $\underline{3}$ & 8 & 27 & CW2 & Female & 0 \\
\hline 23 & 1 & $\overline{9}$ & 8 & $\underline{\mathrm{W}} 40$ & $\mathrm{CW} 3$ & Female & 1 \\
\hline
\end{tabular}

${ }^{a}$ Effector to target ratio $=70: 1$.

${ }^{b}$ The HLA antigens shared with patient 2 are underlined.

TABLE 3. Killing pattern of patient 1 (Mrs. R.) against her HLAidentical sibling donor

\begin{tabular}{|c|c|c|c|}
\hline \multirow{2}{*}{$\begin{array}{l}\text { Time post-trans- } \\
\text { plant (weeks) }\end{array}$} & \multirow{2}{*}{$\begin{array}{c}\text { Mixed leukocyte } \\
\text { culture stimulation } \\
\text { index }\end{array}$} & \multicolumn{2}{|c|}{$\mathrm{CML}^{a}$} \\
\hline & & Direct & $\begin{array}{c}\text { Indirect (specific } \\
\text { stimulation) }\end{array}$ \\
\hline 31 & 2.8 & \multirow{5}{*}{$18 \%$ kill } & $67 \% \mathrm{kill}^{b}$ \\
\hline 42 & 1.1 & & $60 \%$ kill \\
\hline 52 & 1.6 & & $48 \%$ kill \\
\hline 72 & 1.1 & & $13 \%$ kill \\
\hline 74 & 10 & & $3 \%$ kill \\
\hline
\end{tabular}

${ }^{a}$ In the indirect CML effector cells of patient 1 (Mrs. R) were made using cells from her HLA-identical brother as stimulator cells. In the direct CML Mrs. R.'s celis were tested without in vitro stimulation against her HLA-identical brother.

${ }^{b}$ To facilitate the comparison between the percentage of $\mathrm{Cr}$ release, the results are given only of the effector to target ratio, 70:1.

share HLA-A2 have a poorer graft survival than those who do not share HLA-A2.

\section{DISCUSSION}

We have concluded from these data that lymphocytes from two, possibly three patients suffering from aplastic anaemia, recognized HLA-A2-positive male target cells. The low level of killing obtained against some HLA-A2 female target cells suggested that at least one other clone was present that recognized other HLA-A2-associated gene products. This was not surpris- ing, since all such patients received many blood transfusions; 20 in the case of patient 2 and more than a 100 in the case of patient 1 . One would have expected that this would have led to many more reactions directed to non-HLA antigens. The detection of a predominant specificity was thus a surprising observation. It was even more surprising to find that 3 of 14 patients who demonstrated non-HLA killing recognized the same predominant specificities, namely, HLA-A2 and maleness. Patient 2 suffered from a severe aplastic anaemia and was immunized by multiple blood transfusions and pregnancies. Patient 1 , however, had received in addition a bone marrow graft from her HLA-identical brother, which was subsequently rejected. Thus, it follows that blood transfusions and possibly pregnancies are sufficient in themselves to induce HLA-restricted anti$\mathrm{H}-\mathrm{Y}$ cytotoxicity and that bone marrow transplantation was not a necessary prerequisite.

Positive cytotoxic tests directed to HLA-identical siblings have been described before in multi-transfused patients, but these have not been examined for the HLA restriction phenomenon $(8,11,16)$. However, it was remarkable that in all three studies killing was only obtained with patients who carried HLA-A2. Some indication for preferential killing of a male sibling's cells by a female patient's cells was indicated in one case (case 5, Reference (11)). Of the 14 patients studied in our series ( 7 male and 4 female patients carrying the HLA-A2 antigen), 3 cases were found showing preferential killing of male cells by female cells. Several hypotheses are suggested to explain these findings. They include: (1) The presence of a Ir gene 
TABLE 4 Reinduction of A2-restricted antı-H-Y effector cells ${ }^{a}$

\begin{tabular}{|c|c|c|c|}
\hline Responder & \multicolumn{3}{|c|}{ Stimulator } \\
\hline $\begin{array}{l}\text { Bone marrow recipient Mrs } R \text { (patient } \\
\text { 1) }\end{array}$ & \multicolumn{3}{|c|}{ HLA-identical male sibling donor } \\
\hline $\begin{array}{l}\text { Bone marrow recipient Mrs } \mathrm{R} \text { (patient } \\
\text { 1) }\end{array}$ & \multicolumn{3}{|c|}{ Unrelated SD-ıdentical male donor } \\
\hline $\begin{array}{l}\text { Bone marrow recipient Mrs } R \text { (patient } \\
\text { 1) }\end{array}$ & \multicolumn{3}{|c|}{ Unrelated SD-identical male donor } \\
\hline${ }^{a}$ HLA phenotypes & $H L A A$ & $H L A B$ & $H L A$ \\
\hline Patient 1 & 2 & $12 \mathrm{w} 40$ & $\mathrm{Cw}$ \\
\hline Identical sibling donor & 2 & $12 \mathrm{w} 40$ & $\mathrm{Cw}$ \\
\hline Unrelated male donor & 2 & $12 \mathrm{w} 40$ & $\mathrm{Cw}$ \\
\hline
\end{tabular}

TABLE 5 Killing pattern of cells of patient 1 (Mrs R) stımulated in vitro on HLA-A, B, and C-identical but HLA D-different unrelated indıviduals ${ }^{t}$

\begin{tabular}{|c|c|c|c|c|c|c|c|}
\hline \multirow{4}{*}{$\begin{array}{l}\text { Targets } \\
\text { Patient } 1 \\
\text { sib }^{c}\end{array}$} & \multicolumn{5}{|c|}{ HLA Phenotypes } & \multirow{3}{*}{$\frac{\text { Sex }}{\text { Female }}$} & \multirow{3}{*}{$\frac{\% \text { kull }}{-4}$} \\
\hline & \multicolumn{2}{|c|}{$H L A A$} & \multicolumn{2}{|c|}{$H L A B$} & \multirow{2}{*}{$\frac{H L A C}{\text { CW3 }}$} & & \\
\hline & - & $\underline{2}^{b}$ & $\underline{12}$ & W40 & & & \\
\hline & - & $\underline{2}$ & $\underline{12}$ & $\overline{\mathrm{W} 40}$ & $\overline{\mathrm{CW} 3}$ & Male & 68 \\
\hline 1 & - & $\underline{2}$ & 二 & $\overline{\mathrm{W} 40}$ & $\overline{\mathrm{CW} 3}$ & Male & 39 \\
\hline 2 & - & $\overline{2}$ & $\underline{12}$ & $\overline{\mathrm{W} 40}$ & $\overline{\mathrm{CW} 3}$ & Male & 53 \\
\hline 3 & 1 & $\underline{2}$ & 8 & $\overline{27}$ & $\overline{\mathrm{CW} 2}$ & Male & 46 \\
\hline 4 & $\underline{2}$ & $\overline{11}$ & 5 & $\underline{12}$ & - & Male & 42 \\
\hline 5 & $\underline{2}$ & 3 & 7 & 12 & - & Male & 43 \\
\hline 6 & $\underline{2}$ & - & 5 & $\underline{12}$ & CW5 & Male & 70 \\
\hline 7 & 1 & 3 & 7 & 8 & - & Male & -2 \\
\hline 8 & $28^{\circ}$ & 29 & 7 & W15 2 & CW3 CW4 & Male & -8 \\
\hline 9 & 11 & 29 & 8 & W15 2 & $\overline{\mathrm{CW} 3}$ & Male & -2 \\
\hline 10 & $\underline{2}$ & 3 & W17 & W35 & CW4 & Female & -5 \\
\hline 11 & $\underline{2}$ & 9 & 5 & W40 & CW3 & Female & 7 \\
\hline 12 & $\underline{2}$ & W31 & $\underline{12}$ & W35 & CW4 & Female & 2 \\
\hline 13 & $\underline{2}$ & W31 & W35 & $\underline{W 40}$ & $\underline{\mathrm{CW} 3} \mathrm{CW} 4$ & Female & 4 \\
\hline 14 & $=$ & $\underline{2}$ & $\underline{12}$ & $\overline{W 40}$ & $\overline{\mathrm{CW} 3}$ & Female & 10 \\
\hline 15 & $\underline{2}$ & $\overline{3}$ & 7 & $\overline{W 35}$ & $\overline{\mathrm{CW} 4}$ & Female & 6 \\
\hline 16 & $\overline{2}$ & 11 & & W35 & $\mathrm{CW} 4$ & Female & 6 \\
\hline 17 & $\overline{2}$ & 3 & W22 & W35 & CW4 & Female & 0 \\
\hline 18 & & $\underline{2}$ & 8 & $\underline{12}$ & - & Female & 6 \\
\hline 19 & $\underline{2}$ & 3 & 7 & $W 40$ & CW3 & Female & 7 \\
\hline 20 & $\underline{2}$ & 3 & 7 & $\underline{12}$ & - & Female & 7 \\
\hline 21 & 1 & $\underline{2}$ & 8 & $\underline{12}$ & - & Female & 4 \\
\hline 22 & 3 & W26 & & W35 & CW4 & Female & 1 \\
\hline 23 & 11 & W31 & W15 & WW17 & CW3 & Female & -1 \\
\hline
\end{tabular}

${ }^{a}$ HLA phenotype of the stimulator cell HLA-A2, B12, Bw40, Cw3

${ }^{b}$ The HLA antigens shared with patient 1 are underlined

${ }^{c}$ HLA-identical bone marrow donor

TABLE 6 Two-year actuarial cadavenc renal graft survival in Eurotransplant patients sex and HLA-A2 data for male donors and female recipients

Leukocyte antıbody positive group

\begin{tabular}{|c|c|c|c|c|}
\hline Donor & A2 positive & A2 negative & \multirow{2}{*}{$\mathrm{T}$} & \multirow{2}{*}{$\mathrm{p}$} \\
\hline Recipient & A2 positive & A2 negative & & \\
\hline & $\begin{array}{c}38 \% \\
n=48^{a}\end{array}$ & $\begin{array}{c}58 \% \\
n=50\end{array}$ & 196 & 005 \\
\hline \multicolumn{5}{|c|}{ Leukocyte antıbody negatıve group } \\
\hline & $\begin{array}{l}579 \% \\
n=53\end{array}$ & $\begin{array}{c}610 \% \\
n=53\end{array}$ & 024 & 008 \\
\hline
\end{tabular}

${ }^{a}$ At risk after 2 years
HLA-identical male sibling donor

13

HLA identical male sıbling donor

68

Unrelated SD-1dentıcal male donor

53 
erence for sharing of a specific HLA antigen between killer and target cells. The low level of killing of some female target cells in our study indicated that the restriction was not exclusive to H-Y, but nevertheless HLA-A2 seemed to be the restricting antigen.

With regard to the immunological memory of this phenomenon, it was considered of interest to ask how long such reactions persisted after immunization. If they became undetectable, was it possible to reinduce the specific killing? In one case (unpublished data) we were able to detect HLA-restricted H-Y killing 3 years after the last blood transfusion, suggesting that memory was very long-lived.

In the above study patient 1 was monitored for over 74 weeks after the bone marrow transplantation. Although a few blood transfusions were administered during this period, there was a progressive decline in the level of killing obtained with her cells. Despite this it was possible to reinduce high levels of specific killing by priming in vitro with cells from an HLA-A, -B, and -C-identical and HLA-D-different, unrelated male individual This anamnestic response to the HLA-identical male sibling was not only found in patient 1 but was also demonstrated in the other cases. These findings indicated that after primary sensitization, the development of cytotoxic effector cells is dependent on the effect of $\mathrm{T}$ helper cells. These would respond to the foreign HLA-D determinant on the unrelated A2 male cells used for in vitro priming. It is possible that our observations find clarification in the hypothesis of associative recognition proposed by Lake and Mitchison (9), in which they suggested that immunity against non-major histocompatibility complex determinants may more readily be evoked in the presence of major histocompatibility complex alloantigens.

There is some indication that the observations contained in this study may be of relevance in the context of clinical bone marrow and kidney transplantation. In this context it is perhaps relevant to note that bone marrow grafts between HLA-identical siblings have a significantly poorer graft survival if transplanted across a sex difference $(1,12,14)$. Furthermore, a retrospective study of cadaveric renal allograft survival at 2 years showed a significant influence of sex difference between donor and recipient who shared HLA antigens. This only occurred in the antibody-producing group. In previous studies it has been shown that matching for the HLA-A and -B antigens influences graft survival, especially in patients who had formed leukocyte antibodies. In this group matching for HLA-A and -B antigens seemed to be more important than in the antibodynonproducing group, where other as yet unidentified HLA gene products seemed to play a role. The fact that the effect of male incompatibility operated only in the antibody-producing HLA-
A2 group suggested that this group alone could exhibit the HLA-restricted killing. Nonantibody producers on the other hand had a better graft survival than antibody producers (13). Thus, it could be suggested either that this Tatter group was incapable of exhibiting the restricted killing phenomenon or simply that higher levels of suppressor cells were generated in these cases.

One phenomenon remained for which we have no explanation and that was the failure of patient 2 to generate a positive CML when sensitized in vitro to her mother's cells (Table 1). A similar failure to develop positive CML in instances where one might expect this to occur across HLA-incompatible situations was a frequent finding in our studies of patients who had received blood transfusions.

Acknowledgments. We would like to thank Dr. Alan Munro for very useful discussions, Dr. H. L. Haak and Dr. J. M. van Turnhout for the clinical cooperation, C. S. L. Mackenzie and J. C. G. van Nassau for secretarial assistance, E. Blokland for technical assistance, and the staff of Eurotransplant Organization for their cooperation.

\section{LITERATURE CITED}

1. Advisory Committee of the International Bone Marrow Transplant Registry: JAMA (in press)

2. Bevan MJ: 1975 J Exp Med 142: 1349

3. Dickmeiss E, Soeber B, Svejgaard A: 1977 Nature 270: 526

4. Eichwald EJ, Silmser CR: 1955 Transplant Bull 2: 148

5. Gordon RD, Simpson E, Samelson LE: 1975 J Exp Med 142: 1108

6. Goulmy E, Termijtelen A, Bradley BA, et al: 1976 Tissue Antigens 8: 317

7. Goulmy E, Termijtelen A, Bradley BA, et al: Nature 266: 544

8. Jeannet M, Klouda PT, Vassalli P, et al: 1975, p 885 Hustocompatlbulity testing 1975. Munksgaard, Copenhagen

9. Lake P, Mitchison NA: 1976 Cold Spring Harbor Symp Quant Biol 41: 589

10. McMichael AJ, Ting A, Zweerink H, et al: 1977 Nature 270: 524

11. Parkman R, Rosen FA, Rappaport J, et al: 1976 Transplantation 21: 110

12. Storb R, Prentice RL, Thomas ED: 1977 J Clin Invest 59: 625

13. van Hooff JP, van der Steen GJ, Schippers HMA, van Rood JJ: 1972 Lancet 2: 1385

14. van Rood JJ, van Leeuwen A, Goulmy E, et al: Exp Hematol Today (in press)

15. von Boehmer H, Fathmann CG, Haas W.: 1977 Eur J Immunol 7; 443

16. Wunderlich JR, Rogentine GN, Yankee RA: 1972 Transplantation 13: 31

17. Zinkernagel RM, Doherty PC: 1974 Nature 251: 547

Received 20 September 1977.

Accepted 12 January 1978. 